\title{
RHETORICAL COMPETENCE IN SCHOOL LANGUAGE EDUCATION: METHODS OF FORMATION
}

\section{Nyshcheta V. A.}

\section{INTRODUCTION}

In the context of reforming modern general secondary education, the Ukrainian school faces the task of preparing a competent graduate who defines personally meaningful goals, has developed critical thinking, is capable of self-development and self-fulfillment, is ready for life-long learning, able to work in a team, effectively communicating in a multicultural environment, to speak competently and reasonably on the basis of acquired skills.

The priorities identified determine a number of approaches to learning, including competency, which we recognize as one of the leading ones. The implementation of this approach in language education provides the education of a competent speaker, the development of his/her strategic skills, the formation of worldviews, orientation to self-improvement and so on.

Actual problems of general secondary education cause consideration of realities and definition of prospects. The modern school is designed to meet the needs of the society, therefore, the Ukrainian language is of paramount importance - a competently oriented subject, the fundamental task of which is the formation of students' communicative competence as subject and key. One of the priorities of learning the Ukrainian language is the formation of personality of a Ukrainian citizen, nationally conscious, motivated to perceive universal values in the context of world culture that is inclined to interact. Therefore, competences for effective and optimal speech must be formed on the basis of dialogical culture, dialogical consciousness, and dialogical comprehension of reality. An important component of learning is the students' acquisition of the techniques of persuasion, influence and technology of life-building. This task can be solved if the rhetorical aspect of the Ukrainian language is realized, the students are involved in mastering school rhetoric and the formation of rhetorical competence in them.

In the recent history of Ukraine, there is a permanent fluctuation of interest in school rhetoric. The rhetorical aspect of the Ukrainian language was first manifested in the Ukrainian language program in 2005: in accordance with the program requirements, a teacher had to transmit to students certain information about rhetoric; in 10 and 11 grades 5 hours were allocated for studying the basics of practical rhetoric; 12 grade students had 
to study rhetoric directly. In the updated 2013 program, the 12 -year training was abolished, but the content's enrichment of the language line by the subitem "Text (rhetorical aspect)" in each educational topic was envisaged. However, in 2015, the "Text (rhetorical aspect)" sub-item was removed as irrelevant in ensuring a proper level of communication competence in all sections of the language content line of the Ukrainian language curriculum for secondary schools. The Ukrainian language program (2017) for high school again provided for a partial study of practical rhetoric in the development aspect of high school students' speech.

Despite these contradictions, we find it encouraging that pedagogical discourse in the context of rhetorical issues continues to evolve, enriched by considerations about the relevance of rhetoric in school language education. This is explained by the presence in society of the demand for the rhetorical skills of modern person, the enhancement of his/her communicative culture against the background of the crisis of language communication, which is primarily a crisis of a person himself/herself. Methodical traditions of fostering rhetorical abilities of young generations are laid in the school, so we consider our study relevant and timely.

\section{Concepual provisions of the formation process of rhetorical competence}

At the philosophical level of the methodology of pedagogy, humanism as a social and philosophical direction, as a worldview system, recognizing the value of man/woman as a personality, his/her right to freedom, happiness, development, manifestation of abilities, affirms the good of a person as a criterion for assessing social phenomena. Humanistic ideas have become the basis of pedagogy, and humanistic pedagogy - the pedagogy of humanism understands a person from the viewpoint of the self-worth of his/her personality and is oriented towards the realization of his/her personal abilities and capabilities. At the specific scientific level of the methodology of pedagogy in the humanistic paradigm, the following educational approaches have been developed and implemented: personally oriented (I. Bekh, S. Goncharenko, I. Ziazun, V. Kraevsky, I. Lerner, K. Rogers, O. Savchenko, V. Serikov, A. Khutorsky, I. Yakimans'ka), whose central concept is personality in the process of formation, becoming, development; activity (L. Vygotsky, L. Grimak, V. Davidov, I. Drozdova, O. Leontiev, D. McClelland, J. Newtten, G. Allport), whose key concept is not the activity itself, but the personality in the process of activity; competent (N. Bibik, L. Vashchenko, V. Doniy, I. Ermakov, I. Zimnya, V. Kraevsky, O. Ovcharuk, L. Petrovs'ka, L. Pyrozhenko, O. Pometun, D. Puzikov, J. Raven, I. Rodygina, G. Selevko, O. Savchenko, S. Sysoyeva, N. Sophiy, L. Sohan, A. Khutorsky, S. Shevtsova, etc.), the semantic center of which is 
not just competence, but personality in the process of formation, expression, and improvement of competencies.

The competency approach is the core, basic idea of reforming the educational process. According to A. Khutorsky's definition, competence is the possession of relevant competence by a student, which includes his/her personal relation to it and to the subject of activity; therefore, competence is an already acquired personality trait (set of qualities) of a student and minimal experience in a particular field ${ }^{1}$. Similarly to modern national education, the imperative understanding of competence as objective, general, alienated from the subject, and competence as specific, individual, subjective (personal characteristic) is now established.

The analysis of professional literature has shown ambiguity in the views of scholars on the separation of rhetorical competence (RC), so we consider not only as correct but necessary and sufficient the conclusions of N. Golub ${ }^{2}$, who outlined the factors that confirm the expediency of the RC, through the main categories of rhetoric. Therefore, it is logical and expedient to distinguish $\mathrm{RC}$ as the purpose and result of purposeful pedagogical activity in school language education.

On the basis of theoretical and methodological analysis of philosophical, psychological, pedagogical, rhetorical, linguo-didactic primary sources, we determine the following conceptual parameters of the RC:

1) we define $\mathrm{RC}$ as an integrative personal quality, which includes possession of rhetorical knowledge and skills, rhetorical potential, which together determine the ability and willingness to communicate effectively and optimally, implemented and enshrined in the experience of communicative and rhetorical activity;

2) we consider RC as higher than communicative in the system of competencies, since its content is not the experience of communicative activity, but the aggregate experience of communicative and rhetorical activity; the question of the relation between rhetorical and communicative competencies remains open and debatable (especially in school language education) until now;

3) we consider RC in school language education as subject and crosscurricular, arguing such a vision in three aspects: first, in modern rhetoric, the main provisions of which were developed by $\mathrm{H}$. Perelman and L. Olbrechts-Titeka ${ }^{3}$, the context of literary literature has been studied in

${ }^{1}$ Хуторской А.В. Педагогическая инноватика : учеб. пособ. Москва : Академия, 2008. $256 \mathrm{c}$.

${ }^{2}$ Голуб Н. Риторична компетентність учнів старших класів як показник сучасної мовної освіти. Украӥнська мова і література в школі. 2010. № 8. С. 2-7.

3 The New Rhetoric - A Treatise on Argumentation. By Ch. Perelman and L. Olbrechts-Tyteca, translated by J. Wilkinson and P. Weaver. Notre dame, ind. : Notre dame univ. Press, 1968. Pp. 566. 
detail (literature-fiction) (O. Volkov, J. Dubois, O. Zarets'ka, N. Kneht, H. Lemmerman, F. Pir, Y. Rozhdestvensky, A. Trinon, V. Kharchenko); secondly, language and literature as educational subjects at school, according to I. Lerner and V. Kraevsky, have a great deal in common in terms of content (values, knowledge, text, modes of activity, experience of creative activity, etc. $)^{4}$; thirdly, the management of the RC formation process is entrusted to a language teacher whose professional responsibility is to implement the content of school language and literary education;

4) in accordance with A. Khutorsky's hierarchy of competences, the RC may hypothetically receive meta-subject and even supra-subject status in measuring the effectiveness of school education, the reasoning for which should be the content of individual studies, but at present, the acquisition of any status is not possible (except, of course, scientific researches), until rhetoric becomes an imperative component of the content of school language education.

$\mathrm{RC}$ is considered by us as a component of the social experience of secondary school students, so we structurally consider it as a set of readiness, abilities, possibilities, knowledge, skills, customs, habits, values and values-orientations, motivational-needy, psychic and behavioral characteristics, experiences, etc. The structure of the $\mathbf{R C}$ is represented by six components: 1) theoretical and practical (a complex of linguistic and rhetorical knowledge in the context of their proper use in speech and rhetorical activity); 2) procedural activity (skills of intercourse, communication according to the speech situation; applying of skills to use the chosen means to achieve the communicative goal); 3 ) organizational and methodological (skill in choosing strategies and tactics of communication); 4) communicative activity (communicativeness as the initiative, ability to engage in active communication); 5) the impact of a speech act (the ability to possess expressive-emotional means of speech to achieve the intended pragmatic result); 6) moral and ethical - socio-cultural (values, value orientations, spirituality of personality).

The components of the $\mathrm{RC}$ are related to the aspects of communicative competence - figurative-thinking, theoretical, analytical, motivationalevaluative, action-creative, emotional-volitional, conflict-oriented, active listening, cooperation, communication efficiency, non-verbal communication - and this is evidence of the possibility and feasibility of forming $\mathrm{RC}$ in the context of a communicatively directed school language education.

Analyzing the above conceptual provisions, N. Golub expressed a desire to consider two important points in the structure of rhetorical competence:

4 Теоретические основы содержания общего среднего образования / под ред. В.В. Краевского, И.Я. Лернера. Москва : Педагогика, 1983. 352 с. 
"1) the production of a rhetorical text has its own peculiarities: it must be not only informationally rich, but also lexically attractive, emotionally weighted, in order to enrich listener informatively and emotionally, bring him/her pleasure; 2) the speaker's responsibility for every word spoken"5. In full agreement with the scientist, we consider it inappropriate to mention the relevant accents in the general description of the structure, because the information in it is presented in a schematic, not detailed form. The meaning of the comments is acceptable: first, to enjoy the listener's rhetorical text can be a planned pragmatic result of speech, so it is logical to consider this moment (as an aspect of mastering expressive-emotional means of speech) from the viewpoint of influence of speech act; secondly, the speaker's responsibility for each spoken word is certainly a value inherent in the speaker-rhetoric, so we consider this feature in the moral-ethical (sociocultural) aspect, which is stipulated by the requirement to implement the principle of speech act.

Sharing J. Raven's view that competence is a complex integral entity ${ }^{6}$, we consider it correct to understand this term in two aspects: 1) competence is a characteristic of a person's personality, the acquired quality; 2) the essential and substantive field of competence should be considered in the context of the three-stage "knowing-doing-being" structure. Competence is a productive, existential characteristic. It is formed, acquired and manifested in the process of activity, therefore, it contains activity characteristics. Some tools are needed to build competence. The instrumental side of competence can be represented by knowledge, attitudes, competences. Willingness, ability, possibility, skills form the activity background of the process of competence formation (acquisition). An effective, meaningful sense of competence is revealed through the keywords "success" and "experience". Because of these words, in our opinion, it is appropriate to interpret competence as a person's personal quality.

We consider rhetorical skills to be the leading activity characteristics of the RC, which are characterized by the following parameters: 1) based on knowledge of language, rhetoric, knowledge of speech, communication; 2) are a set of general-educational skills, speech actions, elements of speech, communication and rhetorical activity; 3) are acquired by students in the process of purposeful educational activity, in reasonably organized conditions with the involvement of life and communication experience of students; 4) become the basis for the formation of rhetorical competence in students.

${ }^{5}$ Голуб Н. Риторична компетентність учнів старших класів як показник сучасної мовної освіти. Українська мова і література в школі. 2010. № 8. С. 6.

${ }^{6}$ Равен Дж. Компетентность в современном обществе: выявление, развитие и реализация. М. : Когнито-Центр, 2002. 218 с. 
During the research, scientific and methodological sources were analyzed, which resulted in a nomenclature of rhetorical skills ${ }^{7}$. The nomenclature outlines a set of rhetorical skills (69 positions), which, in case of purposefully organized pedagogical activity, can be formed in secondary school students in the process of learning the Ukrainian language. All rhetorical skills are grouped by two classification traits: 1) activity (procedural) characteristics (analytical, criterion-evaluative, transformative, productive, projective, reflective, skills in the volitional, emotional, motivational spheres, interpersonal skills); 2) aspects of rhetorical activity (public, own rhetorical, monological, dialogical, polemical speech, speech situation, rhetorical means, rhetorical knowledge, text, values).

We consider all rhetorical skills as complex, completely agreeing with B. Eismontas's definition: "Complex skills - the ability to consciously perform complex action through a set of skills; skill is the automated execution of elementary actions that make up a complex action performed through the ability" ${ }^{\prime \prime}$. For example: a complex rhetorical ability to create utterance (dialogue) in accordance with the concept, giving expressiveness to its linguistic design implies that a student has the skills (1) to determine the purpose of speech, (2) to design dialogic speech, (3) to use tropes in the speech, (4) use rhetorical figures in speech, (5) use language skills and rhetoric in speech.

Thus, the RC of students is higher than the communicative one in the system of competences, subject and cross-curricular in the field of rhetorical aspect's realization and communicatively directed language education, an organic component of the social experience of the students' personality.

The formation of this integrative personality characteristic, the structure of which is represented by a set of rhetorical knowledge in terms of mastering and practical use in speech and rhetorical activity, rhetorical skills, communication skills, intercourse and communication skills, occurs in parallel with the process of formation of communicative competence as a subject and key in prospecting the process of school language education as a small pedagogical system in the humanistic paradigm of pedagogy on the basis of personally oriented, activity, competence approaches as basic systematic methodological concepts, united by the concept of "personality".

${ }^{7}$ Нищета В. Методика формування риторичної компетентності учнів основної школи : монографія. Київ : Центр учбової літератури, 2017. С. 320-324.

8 Айсмонтас Б.Б. Педагогическая психология: схемы и тесты. Москва : ВЛАДОС-ПРЕСС, 2002. С. 104. 


\section{Methodical aspects of formation of rhetorical competence in school language education}

The implementation of the rhetorical aspect of the Ukrainian language, designed to give students a strong knowledge of the fundamentals of oratorical skills, to promote the formation of skills in the choice of topic, gathering material, planning, composition, use of language, figures, correctness, expressiveness of speech $^{9}$, will be effective if based on the wealth of the spiritual world of each student, the overall development of the individual, knowledge, high activity in social and personal life.

The main ways of forming rhetorical skills are defined in the methodology of teaching the Ukrainian language ${ }^{10}$. Generally agreeing with the developed material, we will express our own experimentally confirmed judgments.

1. Students learn rhetorical theory (categories, laws, rules of rhetoric, etc.) as the key to the effectiveness of entering rhetorical meanings into the process of learning the Ukrainian language, but this process should not necessarily be combined with familiarization / study of the rhetoric history. First, modern rhetoric, based on a thousand-year rhetorical tradition, uses its own methodology, defining as its main purpose not the oratory speech, but the mastery of any person's practice of effective and optimal communication. Secondly, in order to save time of students learning the history of rhetoric at the lesson, it is advisable to organize optional classes. Third, some prominent figures and their works should be briefly introduced in order to get students interested in rhetoric and encourage them to educate themselves.

2. Students' perception of texts (reading, listening) and their subsequent analysis are logically combined with mastering practical means of rhetoric: 1) features of the text (rhetorical aspects, speech design according to the communicative task), directly related to the types of speech and expressive rhetorical means, diction, intonation (elements of speech behavior); 2) realization in the text (statement) of a communicative task, inseparable from linguistic and non-verbal rhetorical means.

3. Creating students' own statements (texts) should be considered as free creativity, as realization of ethos in the speech (self-disclosure of personality), one's own subjectivity, which is one of the defining signs of rhetoric in the text.

\footnotetext{
${ }^{9}$ Методика навчання української мови в середніх освітніх закладах: підруч. для студентів філолог. факультетів університетів / За ред. М.І. Пентилюк. Київ : Ленвіт, 2004. 400 c.

${ }^{10}$ Методика навчання української мови в середніх освітніх закладах: підруч. для студентів філолог. факультетів університетів / За ред. М.І. Пентилюк. Київ : Ленвіт, 2004. C. 119.
} 
4. Students' mastery of the language genres should unite, integrate all directions of rhetorical skills' formation.

The developed program of research-experimental learning of the Ukrainian language envisages realization of three main directions of students' rhetorical skills formation as constituents of RC: 1) mastering of rhetorical theory (rhetorical concepts - categories, laws, rules of rhetoric, basics of aristics, oratorical speech, rhetoric of dialogue, rhetorical means, rhetorical argument, rhetorical norm); 2) processing of sample texts (mastering of practical means of rhetoric on the basis of text; perception of texts, their rhetorical analysis; rhetorical means; rhetorical aspects of the text); 3) text creation (creation of expressions as free creativity; active speaking and writing - monologue, dialogue, polemical speech, oratorial speech). And the integrating factor of the three directions is the mastery of the speech genres by students.

The program's implementation of experimental and research training should take place against the background of the introduction of educational approaches: personality-oriented, activity-oriented, competent, communicative-activity, functional and stylistic, socio-cultural, problematic, project and rhetorical as a general one.

We define the rhetorical approach in school language education as a set of pedagogically expedient theoretical, methodological and applied measures aimed at mastering effective and optimal speech and applied in the process of language learning, the subjects of which are involved in conscious and reflective speech communication using linguistic and rhetorical means in different forms, spheres and genres of speech. We outline the following parameters of the rhetorical approach:

1) strategic idea (goal) - formation of rhetorical skills and RC of students in the process of language learning;

2) the principles of school language education - positive pedagogical interaction, harmonizing dialogue, axiologization, anthropocentricity, formation of personality through words, developmental influence, active perception, civic education, heuristic, "lively communicativeness", "speech act", spiritual formation of personality;

3) the categorical apparatus of the rhetorical approach in language learning: effective speech - effective, resultative communication, for which only the speaker attains his/her goal, with a possible loss for the listener; optimal speech - communication in which the achievement of the goal by the speaker is combined with the beneficial consequences for the listener; speech communication is a thought-and-speech activity carried out for the purpose of interaction; rhetorical text - a product of rhetorical activity directed at other subjects through communicative activity, non-artistic, authorial, address text that realizes the intention of the subject to influence in a specific communication situation; rhetorical dialogue - a dialogue that is 
constructed as the interaction of equal subjects discussing one topic by conventional means, agreeing on the meaning according to the general rules; rhetorical means - the verbal and non-verbal mechanisms used to influence them; rhetorical activity - a particular communicative activity to create and work with a rhetorical text directed at other subjects; speech act - a specially created statement that reflects the moral position of the communicant, whose purpose is to influence the addressee in a crisis situation of communication; reflection is an internal rhetorical dialogue in which the subject knows how to be an addressee for himself/herself.

The rhetorical approach in school language education as a linguisticdidactic category is included in the thematic group of educational approaches by the way of subjective organization of educational activity (from the viewpoint of subjects of language learning and subjective interaction). The implementation of the approach in the practice of school language education requires the reorganization and transformation of all units of the educational process, since it affects all areas of professional activity of a language teacher, and therefore directs him/her to a comprehensive effort.

A necessary and sufficient condition for the effective implementation of a rhetorical approach to practice is rhetoric activity which is a phenomenon that accumulates the entire set of applied aspects of the process. As a result of the analysis of professional literature, it should be noted that rhetoric (1) signifies a gradual purposeful "entry" of rhetoric and rhetorical into the educational process of the modern school; (2) is formulated using the keywords "comprehension", "rethinking", "activation", "transformation", "mastering of ways"; (3) provides for the realization of rhetorical meanings ("rhetorical knowledge", "rhetorical activity", "categories of rhetoric ethos, pathos, logos", "rhetorical situation", "dialogue", "linguistic (rhetorical) genres", "rhetorical norm", "agonal interaction").

Among the traditional teaching methods, we emphasize the importance of using descriptive and problematic narration of a teacher in the process of experimental learning of the Ukrainian language, the evidential (argumentative) explanation, the method of heuristic conversation, the method of observing linguistic and speech units and phenomena, method of exercises, etc.

The use of specific (peculiar) teaching methods aimed at mastering students' practical communication and rhetorical skills is important.

Rhetorical exercises, according to the typology of N. Golub, are divided into: 1) preparatory (aimed at forming the ability to psychologically adjust oneself to a successful speech, determine the topic of the speech, formulate a goal, thesis, model the audience, select and process the material); 2) training (promote the training of breathing, voice, diction, intonation, memory; practicing gestures and facial expressions; forming skills to speak in parts 
and completely); 3) creative exercises (aimed at shaping skills in a compositionally, logically and stylistically correct way to build a text of a speech, use elements of audience interest; 4) analytical (develop analytical thinking, form the ability of rhetorical analysis of the text or parts of it, analysis of a specific situation, public speaking) ${ }^{11}$. According to our classification of rhetorical skills by aspects of rhetorical activity, the first group of exercises promotes the formation of separate rhetorical skills in the students regarding rhetorical knowledge, their own rhetorical speech, speech situation, text; the second group - rhetorical means of dialogical, public, polemical, and rhetorical speech itself; the third group - text, speech situation, rhetorical means of dialogical, public, polemical, and rhetorical speech itself; fourth group - text, speech situation, public speaking.

A special place in experimental and research training is given to the situational method, which involves the operation by students of the subject (involves the implementation of learning activities with language material to form linguistic competence) and of communicative situations (situations of relationships aimed at forming communicative competence) at the lessons, relying on students' awareness of their behavior at different levels (cliches, "roles", "deadlock", "internal explosion" / "death") ${ }^{12}$. Note on the principled positions: 1) the need to manage rhetorical situations, which provide (a) mandatory updating of the speech and life experience of students, the analysis of successes and failures in communication - the key to motivation to master rhetorical skills and (b) analysis of the implementation of motives from the viewpoint of effectiveness / optimality of communication, which is directly aimed at the formation of RC; 2 ) focusing on students' role-plays in speech behavior, which allows them to direct their activities to develop adaptive rhetorical skills and abilities to vary their behavior (a) within the "Adult - Parent - Child" triad and (b) in the context of the dualism context "Equality - Hierarchy", "Friendship - Alienation", "Struggle Cooperation" ${ }^{13}$; 3) the possibility of considering the situational method as an admission in the process of using methods developed in the methodology of teaching rhetoric ${ }^{14}$ (rhetorical analysis, rhetorical tasks, rhetorical games, improvisational tasks, etc.).

Rhetorical analysis of the text involves taking into account the essential components of the speech situation, which requires understanding them from

${ }^{11}$ Голуб Н. Система вправ з риторики. Украӥнська мова і література в школі. 2011. № 6. С. 2-9.

${ }^{12}$ Голуб Н. Ситуаційний метод на уроках української мови в школі. Українська мова і література в школі. 2013. № 7. С. 18-23.

13 Педагогічна майстерність : підручник / За ред. І. А. Зязюна. Київ : СПД Богданова А. М., 2008. С. 96-98.

${ }^{14}$ Обучение общению: методика школьной риторики : учеб. пособ. / Под. ред. Т.А. Ладыженской. Москва : Баласс, 2013. 144 с. 
the standpoint of rhetoric, the degree of communicative tasks' realization by speakers, a measure of effectiveness and optimality of speech. A specific kind of rhetorical analysis of the text is the analysis of public (rhetorical) speech $^{15}$.

Rhetorical analysis is directly related to the method of rhetorical tasks, the purpose of which is to teach text implementation / expression as a rhetorical genre, taking into account the components of the speech situation and the proposed communicative intention. Adding an element of competitiveness to a rhetorical task, we get rhetorical games (to complete the task faster, more fun, harsher, louder, more precisely, with the help of motions, only by means of verbal behavior, silently by motions alone, etc.). The conduct of rhetorical games involves the presence of arbitrators from among the most prepared students whose task is to determine the winners of the competition.

The acquisition of speech genres and the methods described are related to the method of improvisational tasks, the purpose of which is to involve students in spontaneous performances before the audience. The method is used as a training and as a means of controlling the formation of rhetorical skills. In this case, students are introduced to the assessment criteria (compliance with the speech standards, implementation of the speech genre, non-verbal behavior, efficiency and optimality of speech, etc.).

The main part of the proposed methods involves the active interaction of students, moreover, the rhetorical sense, for example, in improvisational tasks, provided a monologue speech to classmates, is manifested in the mandatory consideration of the students' active position (perception, hearing, intellectual and emotional change), in the targeting of rhetorical speech, in the realization of the pathos of the speaker on the basis of the audience's ethos.

We have noted that in the process of research and experimental learning of the Ukrainian language the mastery of students of the speech genres unites, integrates all directions of rhetorical skills' formation. Considering the text as a unit of communication based on the real situation, we perceive the text as a genre, as a statement endowed with a specific genre specificity, so in the process of forming the RC secondary school students treat all aspects of textual issues in the context of speech genres.

The mastering of rhetorical genres begins with the acquisition by students of the definition of the "rhetorical genre" concept and features of the genre: 1) communicative purpose (informing, influencing, informing in combination with influence); 2) subjects of potential genre dialogue - the

${ }^{15}$ Голуб Н. Методом щоденних вправ: практичні аспекти риторизації вивчення української мови та літератури в школі. Украӥнська мова й література в середніх школах, гімназіях, ліцеях та колегіумах. 2008. № 5 (68). С. 42-52. 
image of the author in relation to the addressee (character, social status, degree of interest, role position, etc.); 3 ) the image of the addressee (degree of acquaintance with the author, official / unofficial person, interest in information, other components of the speech situation); 4) content - the event (plot) basis of expression (past - present - future) determines either the orientation to the communicative past or the possibility of reactions in response; 5) linguistic means - a formal organization (use of characteristic linguistic units, stylistically colored lexical and grammatical forms).

The system for processing speech genres includes:

- identification of genre characteristics (communicative purpose, subjects of potential genre dialogue, content, linguistic means);

- analysis of communicative and life experience of students in the process of the text-genre perception;

- variation of speech behavior ("Adult - Parent - Child", "Equality Hierarchy", "Friendship - Alienation", "Struggle - Cooperation");

- realization of the goal (speech efficiency / optimization of speech).

The decisive feature of the speech genre is the communicative purpose, according to which they are classified into informational, influential and informational-influential, so we define this characteristic throughout the experimental training, constantly emphasizing that even information genres have a potential influence. We consider the characterization of the communicative goal realization as key, since the categories "communication effectiveness" and "communication optimality" are in the author's definition of the RC, so in this aspect we characterize all the speech genres. Similarly, in the course of research and experiential learning, we determine the author and the recipient of the message.

To continue the line of the RC interpretation as a cross-curricular and in the context of the principle of cross-curricular relations' implementation, we study the language genres at the lessons of the Ukrainian literature (for example, studying the genre of folk or literary fairy tales), and not only in the sense of consolidating the studied material at the Ukrainian language lessons.

Characterization of speech genres in terms of content (event (plot) basics of expression) in the 5th grade is carried out in part, forming the idea that this element in different speech genres is different. For example, song and verse (lyric genres) realize the communicative purpose of influencing the emotional and volitional sphere of the addressee's personality and are not related to the spatiotemporal parameters, as well as the riddle, the communicative purpose of which is to plunge the addressee into the situation of volitional, mental, speech tension in an atmosphere of increased interest in solving the problem. In this way, students become aware of the variability of the story's bases manifestation in expression. 
Similarly, we analyze the formal speech organization of speech genres from partial characterization to complete, based on the level of students' acquisition of linguistic concepts and phenomena, their functional-stylistic characteristics, as well as rhetorical means (tropes, figures) on the cognitive (subjective awareness of information and personality) and operational (awareness of how to act with language units and ability to use them in speech) levels.

One of the pedagogical conditions for the effectiveness of the RC formation in the process of experimental and research learning of the Ukrainian language is the development of a system of rhetorical exercises and their use in educational activities, which leads to the linguo-didactic analysis of the «exercise method» concept.

According to the conclusions of $\mathrm{O}$. Kucheruk, the model of the exercises' method is as follows: 1) explanation by a teacher of the task of the exercise (the teacher offers methods of solving the task); 2) performing the exercise by a student using the appropriate method; 3 ) control by the teacher of the exercise or the organization of self-control or mutual control of students ${ }^{16}$. Perceiving the logic of the scientist, we extend it to the problems of the method of rhetorical exercises: we offer students rhetorical tasks (exercises), explain their solution through other methods (situational, rhetorical analysis, analysis of public (rhetorical) speech, rhetorical tasks, rhetorical games, improvisational tasks, work with text, processing of speech genres), we organize complex control of task performance with the use of active reflection of all subjects of the educational process.

The central link of all rhetorical exercises is situational tasks (direct or indirect analysis of speech situations that students perform in verbal or thinking forms), the work with which precedes or accompanies the course of processing tasks of different types. Rhetorical analysis and analysis of public (rhetorical) speech (including analysis of communication situations) are presented as separate methods and fragmentary techniques as part of improvised tasks, rhetorical tasks and rhetorical games. On the other hand, we consider rhetorical exercises in the context of the implementation of the text-centricity (text-oriented) principle - working with texts (ready study texts-samples) and on texts (modeling, designing, creation of primary and secondary educational texts), understanding any educational text as textgenre.

Didactic tools (methods, techniques, forms of training) in the process of the program implementation of experimental and research training are intended to be used with the gradual complication of communicative and

${ }^{16}$ Кучерук О.А. Система методів навчання української мови в основній школі: теорія і практика : монографія. Житомир : Вид-во ЖДУ ім. І. Франка, 2011. С. 359. 
rhetorical content of the learning taking into account the age and individual mental characteristics of students, as well as their level of learning.

Therefore, the implementation of the developed method of RC formation in students in the process of school language education has confirmed its effectiveness and the hypothesis that the process of the planned quality formation will be effective under the following conditions: 1) realization of experimental-research teaching of the Ukrainian language on the basis of personally oriented, active, competent, communicative activity, functionalstylistic, socio-cultural, problematic, project, technological and rhetorical approaches (we define the rhetorical approach as a leading one); 2) organization of the educational process with following general didactic and lingvodidactic principles, as well as specific principles of school rhetoric; 3) integration in the didactic process of traditional methods and elements of cooperative learning (interactive method and forms of teaching); 4) developing a system of rhetorical exercises on a textual and dialogic basis; 5) permanent rhetorization implementation of the Ukrainian language school course, speech development of students and educational tasks.

\section{CONCLUSIONS}

There is such a situation in the Ukrainian language school education where only high school students can get acquainted with rhetoric and master the rhetorical content. In such circumstances, it is possible to talk about the formation of only certain rhetorical skills in schools' graduates, and not about a full-fledged RC, as provided by the competence approach. In our opinion, any competence is a component of social and personal life experience, and it is necessary to start the process of rhetorical skills' formation earlier, in primary school, which is not provided by the current educational programs. In such circumstances, the implementation of the rhetorical aspect of the Ukrainian language depends directly on the motivation of a language teacher, his/her pedagogical skills, innovative thinking, and professional creativity. Experimental studies of Ukrainian scholars can and should be completed as a basis and foundation for pedagogical activity of the modern teacher.

The presented method of RC formation of primary school students in the process of teaching Ukrainian (1) was tested at numerous science events, (2) experimentally confirmed during the pedagogical experiment in 20132017 (participants of the experiment - 124 teachers of the Ukrainian language and literature and 56 students from 11 institutions of general secondary education in all regions of Ukraine), (3) proved effective (the dynamics coefficient of qualitative changes in the experimental classes for individual content parameters ranged from $8 \%$ to $52 \%$ and $26 \%$ by the general level) what is (4) confirmed by statistical methods according to Pearson's criterion. 
We see the prospect of further research in the development of linguistictactical support for the introduction of the author's method of the RC forming and its widespread use in school language education.

Rhetorization as a necessary and sufficient condition for effective implementation of the rhetorical approach to the school language education and the content and activity background of the method of the RC formation is a complex linguistic-educational phenomenon, connected with pedagogical technologies, so the material about it will be published in a separate work.

\section{SUMMARY}

The article deals with the problem of rhetorical competence formation of primary school students in the process of learning Ukrainian. The relevance of scientific issues is confirmed by a public need in the rhetorical skills of a modern person and the current normative documents. The paper describes the conceptual parameters of rhetorical competence, its structure and the correlation of its components with aspects of communicative competence. One of the leading conditions for the formation of rhetorical competence is the rhetorical approach in school language education, which is characterized in detail in the work (definition, principles, categorical apparatus). The author's method of forming the rhetorical competence of primary school students is described: directions and stages of rhetorical skills' formation, the program aspects of experimental-research learning of the Ukrainian language, peculiarities of the rhetoric processes in the context of introducing a rhetorical approach, traditional and special (specific) teaching methods (rhetorical exercises, situational method, rhetorical analysis of the text, method of improvisational tasks, rhetorical tasks, rhetorical games, method of exercises), system of work on processing of speech genres. The presented method of rhetorical competence formation has been scientifically tested, experimentally confirmed during the pedagogical experiment, its effectiveness is proved, which is confirmed by statistical methods.

\section{REFERENCES}

1. Айсмонтас Б. Б. Педагогическая психология: схемы и тесты. Москва : ВЛАДОС-ПРЕСС, 2002. 208 с.

2. Голуб Н. Методом щоденних вправ: практичні аспекти риторизації вивчення української мови та літератури в школі. Украӥнська мова й література в середніх школах, гімназіях, лічеях та колегіумах. 2008. № 5 (68). С. 42-52.

3. Голуб Н. Риторична компетентність учнів старших класів як показник сучасної мовної освіти. Українська мова $i$ література в школі. 2010. № 8. С. 2-7. 
4. Голуб Н. Система вправ 3 риторики. Українська мова i література в школі. 2011. № 6. С. 2-9.

5. Голуб Н. Ситуаційний метод на уроках української мови в школі. Українська мова і література в школі. 2013. № 7. С. 18-23.

6. Кучерук О.А. Система методів навчання української мови в основній школі: теорія і практика : монографія. Житомир : Вид-во ЖДУ ім. І. Франка, 2011. 420 с.

7. Методика навчання риторики в школі : навч. посіб. / авт.-укл. В. А. Нищета. Київ : Центр учбової літератури, 2014. 200 с.

8. Методика навчання української мови в середніх освітніх закладах: підруч. для студентів філолог. факультетів університетів / За ред. М.І. Пентилюк. Київ : Ленвіт, 2004. 400 с.

10. Обучение общению: методика школьной риторики : учеб. пособ. / Под. ред. Т.А. Ладыженской. Москва : Баласс, 2013. 144 с.

11. Педагогічна майстерність : підручник / За ред. I.А. Зязюна. Київ : СПД Богданова А. М., 2008. 376 с.

12. Педагогическое речеведение : словарь-справочник / Сост. А. А. Князьков; под ред. Т. А. Ладыженской и А. К. Михальской. М. : Флинта; Наука, 1998. 312 с.

9. Нищета В. Методика формування риторичної компетентності учнів основної школи : монографія. Київ : Центр учбової літератури, 2017. $340 \mathrm{c}$.

13. Равен Дж. Компетентность в современном обществе: выявление, развитие и реализация. Москва : Когнито-Центр, 2002. 218 с.

14. Теоретические основы содержания общего среднего образования / под ред. В.В. Краевского, И.Я. Лернера. Москва : Педагогика, 1983. $352 \mathrm{c}$.

15. Хуторской А. В. Педагогическая инноватика : учеб. пособ. Москва : Академия, 2008. 256 с.

16. The New Rhetoric - A Treatise on Argumentation. By Ch. Perelman and L. Olbrechts-Tyteca, translated by J. Wilkinson and P. Weaver. Notre dame, ind. : Notre dame univ. Press, 1968. Pp. 566.

\section{Information about the author:} Nyshcheta V. A.,

Doctor of Pedagogical Sciences, Associate Professor of the Department of the Ukrainian Language and Slavic Studies

Berdiansk State Pedagogical University 4, Schmidta str., Berdiansk, Zaporizhzhia region, Ukraine 